\title{
Blue oak stump sprouting evaluated after firewood harvest in northern Sacramento Valley
}

\author{
by Richard B. Standiford, Douglas McCreary, \\ Sheila Barry and Larry Forero
}

California's hardwood rangelands, an oak-dominated woodland system, cover 10 million acres. More than $80 \%$ of these lands are privately owned, with two-thirds grazed by domestic livestock. Public concerns about long-term damage to habitat in areas harvested for firewood - particularly in the northern Sacramento Valley - led to this study of resprouting, to assess long-term trends in oak cover following harvesting and the potential of sprout (coppice) management to sustain woodlands. In field surveys on 103 sample plots at 19 ranches where oak firewood was harvested, we found that $54 \%$ of all oak stumps resprouted. Stump diameter, herbicide application, overstory crown cover percentage, and slope and aspect were significant variables in models developed to assess the probability of stump sprouting. Ten-year sprout height and crown growth models were developed, and livestock grazing, residual overstory canopy, herbicide treatment and stump diameter were found to be significant variables. These models can be used to predict stand development following firewood harvest and can be integrated with forage growth, wildlife habitat and residual tree growth models.

Ca alifornia's hardwood rangelands cover 10 million acres, or $10 \%$ of the state (Bolsinger 1988). The overstory tree canopy is predominantly oaks (Quercus spp.) with an understory of exotic annual grasses and forbs, and occasional native perennial grasses (Bartolome 1987; Standiford 2001). The five major oak species occurring on hardwood rangelands include three deciduous white oaks — blue oak

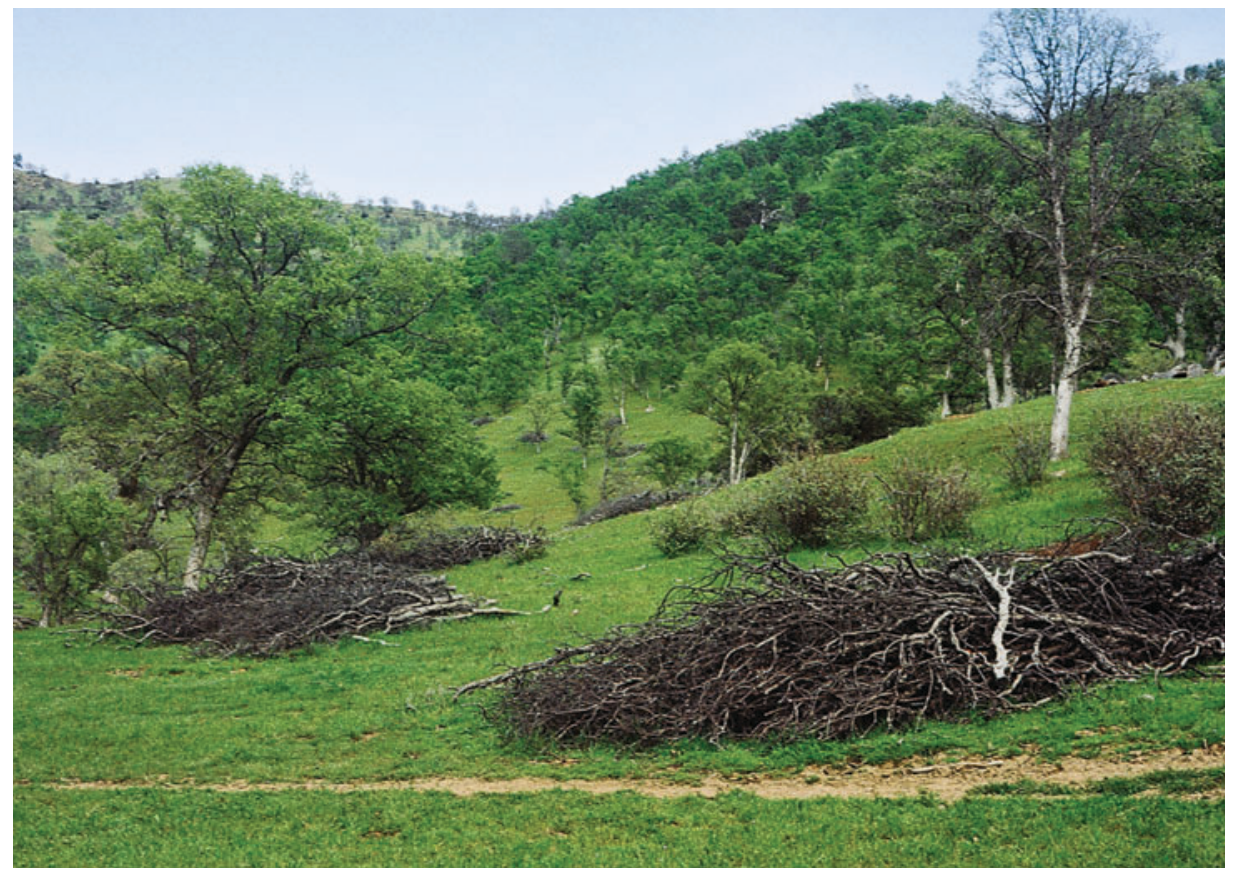

Oak woodlands support thousands of native plant and animal species, improve water quality, and provide aesthetic and recreational opportunities. More than $80 \%$ of California's oak woodlands are under private ownership, utilized for livestock grazing and, to a lesser extent, firewood harvesting. Above, a harvested study site in Tehama County.

(Quercus douglasii Hook. \& Arn.), valley oak (Quercus lobata Nee) and Engelmann oak (Quercus engelmannii Greene); and two evergreen oaks - coast live oak (Quercus agrifolia Nee) and interior live oak (Quercus wislizeni A. DC.).

Since European settlement of California, oak woodlands have been managed primarily for livestock production. These areas have high public value because of their rich species abundance, with over 300 vertebrate, 5,000 invertebrate and 2,000 plant species (Garrison 1996). Oak woodlands also contribute greatly to water quantity and quality, outdoor recreation and aesthetics. Over $80 \%$ of oak woodlands are in private ownership (Huntsinger et al. 1997).

Firewood has been harvested from oak woodlands since the late 1700s (Pavlik et al. 1991), and woodcutting continues to occur throughout the state. The primary reasons are to generate additional cash flow from the sale of firewood, primarily associated with periods of low livestock prices; to increase forage production; and to improve habitat for game species
(Standiford and Howitt 1993). Aerial surveys in the early 1990s showed that firewood harvesting was concentrated in Shasta and Tehama counties, in the northern Sacramento Valley. These two counties contain about $5 \%$ of the state's total hardwood rangelands but produced over $40 \%$ of all firewood harvested between 1988 and 1992 (Standiford et al. 1996). The two primary species harvested were blue oak and interior live oak.

Basal or stump sprouting following wildfire or tree harvest is common for many oak species and is the primary mechanism for oak regeneration in this study area. (A separate study, not reported here, showed limited regeneration from seedlings derived from acorns.) Numerous studies of the U.S. East, Midwest and South have evaluated the sprouting phenomenon, including the relationship between sprouting and harvest season (Geisinger et al. 1989; Johnson 1977;

Online: http://californiaagriculture.ucanr.org/ landingpage.cfm?article=ca.v065n03p148\&fulltext=yes DOl: 10.3733/ca.v065n03p148 
Roth and Hepting 1943); the relationship between tree size and sprouting response (Clark and Liming 1953; Dey et al. 2008; Johnson 1975; Lockhart and Chambers 2007; Roth and Hepting 1943); the sprouting capacity of different oak species (Johnson 1979; Liming and Johnston 1943; Weigel et al. 2006) and age classes (Rogers and Rogers 1959); and the effect of site quality (Weigel et al. 2006; Weigel and Peng 2002).

Little information has been available about native oak sprouting in California. Leiberg (1902) observed aggressive stump sprouting of oaks in the Sierra Foothills following extensive harvesting and fires. Several years later, Jepson (1910) also noted extensive sprouting of small blue oak trees harvested to increase pastureland. On coastal foothill woodlands, Longhurst (1956) found that evergreen oaks sprouted better than deciduous oaks, and that there was a tendency for sprouting to decline with age for deciduous species.

The sprouting of native California oaks plays a vital ecological role. Plumb and Gomez (1983) noted that sprouting of dormant buds was the most important adaptation of oaks to fire. McClaren and Bartolome (1989) determined that a large percentage of existing trees in their study area became established within a year of fire, suggesting that many trees in the stand originated from sprouts. Mensing (1992) came to a similar conclusion in an examination of the age class distribution of blue oaks in the Tehachapi Mountains, reporting that top killing of previously established seedlings and saplings by frequent, relatively intense fires resulted in pulses of regeneration.

Finally, McCreary et al. (2008) conducted a series of experiments at five field sites throughout the state to examine the relationship between blue oak sprouting and season of harvest, the height of cut stumps and protection from browsing. In spite of the common belief that blue oak is a relatively poor sprouter, sprouting at most study locations was quite vigorous. In addition, the time when trees were cut had little influence on sprouting, while stump height and protection from browsing were exceedingly important.

Our study was designed to address several unknown areas of hardwood rangeland sustainability. The primary objectives were to develop baseline information on oak sprouting following harvesting and to develop predictive models of sprout survival and growth for use by resource managers and landowners.

\section{Study of harvested woodlands}

We identified 40 private hardwood rangeland owners in Shasta and Tehama counties who had conducted firewood operations in the previous 10 years. For each operation, the location, elevation, soil type, cover type (Allen et al. 1991) and years since harvest were collected. From this list, a random selection of owners was made, stratifying by county and number of years since harvest. Nineteen study sites were selected, representing approximately half of all identified locations. Twelve study sites were selected in Tehama County and seven in Shasta County, approximately proportional to the relative oak woodland acreage in each county. Additional information was collected from each study site on types of grazing practices (season of use, type of animal), as well as other management factors (use of herbicides on harvested stumps, use of prescribed fire, supplemental feeding and range fertilization).

Five to seven 0.1-acre circular plots were randomly established at each study location. This plot size has been used in previous studies of blue oak stand structure and adequately captured site variability (Standiford 1997; Standiford and Howitt 1988; Standiford et al. 1997). An area was selected if there was at least one stump within the plot. The slope, aspect and elevation of each plot were recorded. Residual dry matter of the grass and forb species was estimated using a photo series for California annual grasslands (Clawson et al. 1982). For each stump within the sample plots, information was collected on species, stump height, stump diameter, presence and number of sprouts, dimensions of the sprout crown, height of the tallest sprout and diameter at breast height $(\mathrm{DBH}=4.5$ feet $)$ of the sprout if it was tall enough.

Species, total height, basal diameter, $\mathrm{DBH}$ and crown dimensions were recorded for all uncut, living and dead trees on each plot. Trees inside the plots having special wildlife characteristics (snags, granary trees, trees with cavities, etc.) were also noted and used in the separately reported wildlife survey (Garrison and Standiford 1997). At each location, the oak site index was calculated using the height and diameter of each dominant tree (Standiford and Howitt 1988).

In a random direction from the plot centers, we also ran a 100-foot-long line transect and a 100-foot-by-4.36-foot (0.01 acre) belt transect. Within the belt transect, all seedlings were recorded by height class. The line transect was used to record the percentage cover of understory shrub species, rocks and brush piles, and the amount and size of dead and down woody debris.

The preharvest and postharvest tree stand structure was constructed for

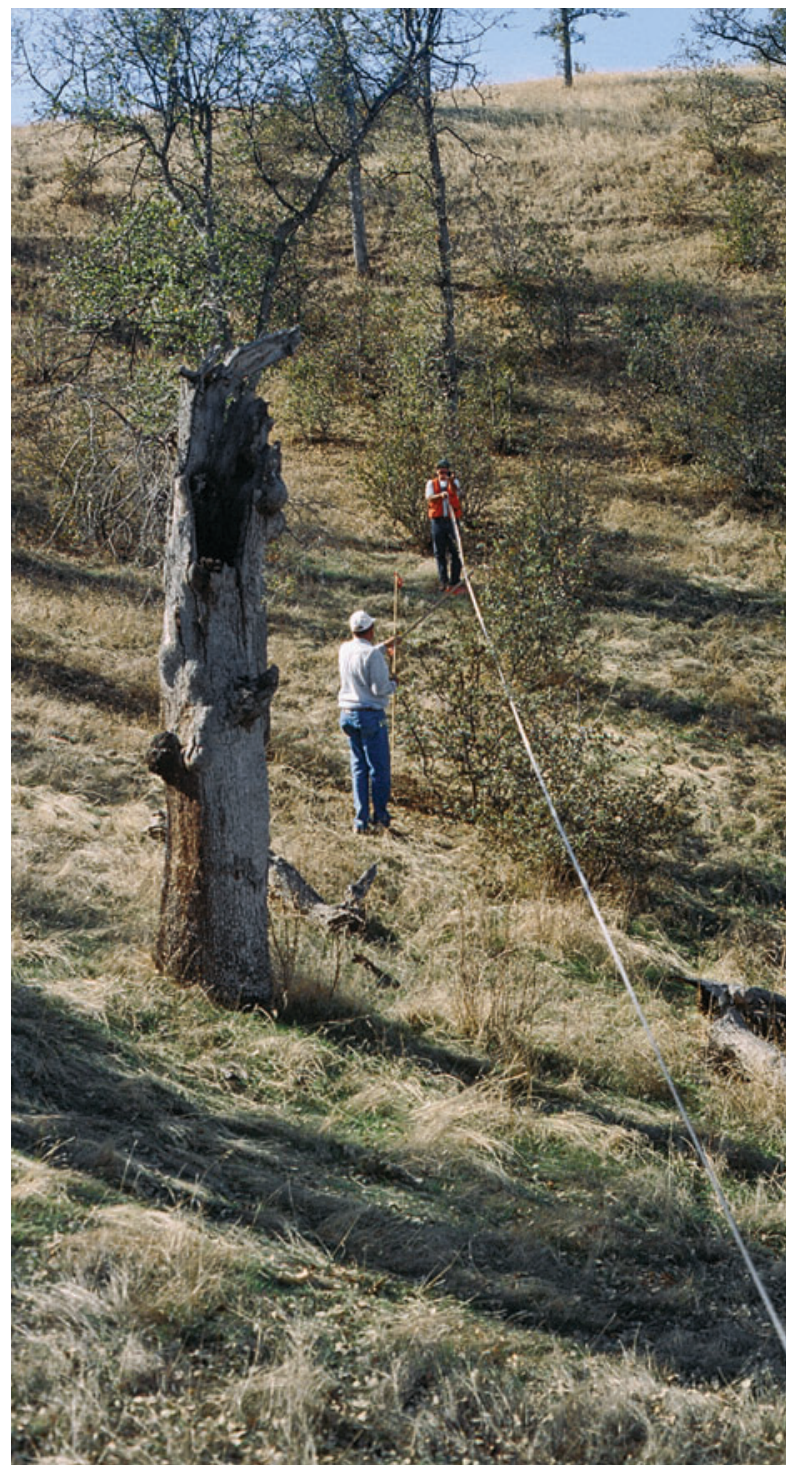

Researchers studying the role of stump resprouting in the regeneration of harvested native oaks measured a 100 -foot-long line transect. 


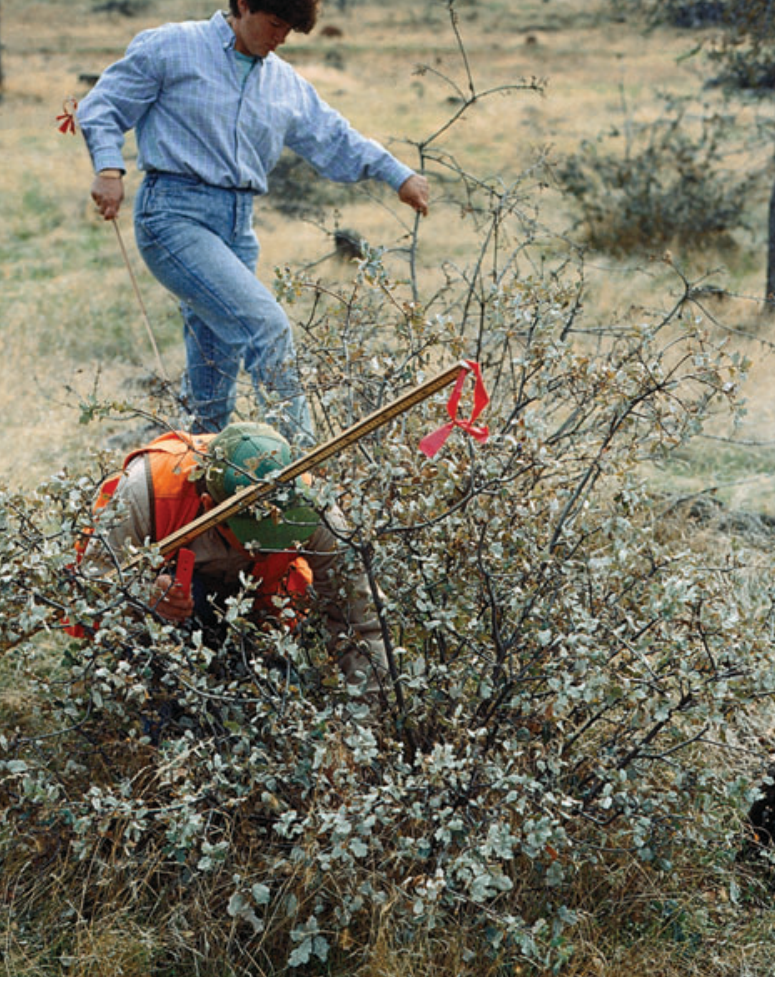

Santa Clara County natural resource advisor Sheila Barry (standing) and staff research associate Jerry Tecklin examined sprouts from a harvested blue oak stump.

TABLE 1. Average pre- and postharvest oak woodland stand structure on 19 study sites in Tehama and Shasta counties following firewood harvest

\begin{tabular}{lcc}
\hline \hline Characteristic & Preharvest & Postharvest \\
\hline $\begin{array}{l}\text { Oak canopy cover (\%) } \\
\text { Volume (cubic feet }\end{array}$ & $737(28)^{*}$ & $15(14)$ \\
per acre) & $259(305)$ \\
$\begin{array}{l}\text { Trees per acre } \\
\text { (number) }\end{array}$ & $219(544)$ & $49(63)$ \\
$\begin{array}{l}\text { Basal area per acre } \\
\text { (square feet) }\end{array}$ & $51(29)$ & $16(17)$ \\
\hline * Standard deviations in parentheses. &
\end{tabular}

each sample plot. A relationship was developed to describe total tree height, DBH and canopy area as a function of the basal diameter of each living tree for each ranch. This relationship was used to develop the preharvest $\mathrm{DBH}$, total height and canopy area for each stump in the sample plot. Individual tree volumes in cubic feet per acre were calculated from equations developed by Pillsbury and Kirkley (1987). The sum of the individual trees before and after harvest gave the tree basal area, canopy cover and tree volumes of each plot and provided a measure of the intensity of the tree harvest.

\section{Statistical models developed}

All study areas were predominantly blue oak woodlands, with a scattering of interior live oaks. We measured 1,194 individual stumps, of which 1,150 were blue oak. Of the 517 individual, living, residual overstory trees measured, 482 were blue oaks. Table 1 shows the intensity of the tree harvest in the study area. Statistical models were developed for the probability of stump sprouting, sprout height growth and sprout crown growth. Because of the limited sample size for interior live oak, the results were limited to blue oaks.

Sprouting percentage. We found a strong negative correlation between sprouting probability and stump diameter (fig. 1). Of 1,194 stumps in this study, $54 \%$ sprouted after harvest. The hypothesis tested was that stump-sprouting

EQUATION 2. Logistic equation developed to evaluate sprouting probability

$$
\text { SPROUT }=\frac{1}{1+\mathrm{e}^{-(1.4606-0.06799 \times \mathrm{DBH}-0.0581 \times \text { HERB }-0.77631 \times C C-0.00937 \times \mathrm{SL}+0.35120 \times \mathrm{ASP})}}
$$

TABLE 2. Logistic regression of blue oak sprouting probability

\begin{tabular}{lc}
\hline \hline Variable & Coefficient (significance) \\
\hline SPROUT = probability of stump sprouting $(0=$ no sprout, $1=$ sprout $)$ & (dependent variable) \\
Constant & $1.60510\left(^{* * *}\right)$ \\
DBH = preharvest diameter at breast height in inches & $-0.17186\left(^{* * *}\right)$ \\
HERB = cut stump treated with herbicide $(1=$ yes, $0=$ no) & $-0.73341\left(^{* * *}\right)$ \\
CC = postharvest overstory crown cover (expressed as decimal & $-1.18680\left(^{*}\right)$ \\
between 0 and 1$)$ & \\
SL = slope percent & $0.00870\left(^{*}\right)$ \\
ASP $=$ aspect of slope $(1=$ south, $0=$ north) & $0.22413\left(^{* *}\right)$ \\
Equation significance & $\left({ }^{* * *}\right)$ \\
Proportion correct predictions & 0.68 \\
\hline${ }^{*}=$ significant at 0.10 level; ${ }^{* *}=$ significant at 0.05 level; ${ }^{* * *}=$ significant at 0.01 level. &
\end{tabular}

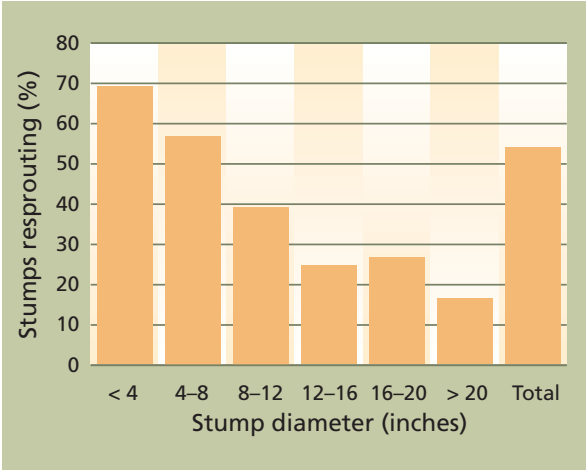

Fig. 1. Relationship between stump diameter and sprouting percentage for cut oak stumps in Shasta and Tehama county study areas.

probability is a function of site and management factors, tree size (DBH) and residual overstory tree cover (equation 1). The predicted value of the dependent variable, SPROUT, can be interpreted as the probability of a particular stump sprouting.

\section{(1) SPROUT $=f$ (site factors, management factors, stump size, species, residual tree cover)}

Since the dependent variable, SPROUT, is a discontinuous variable having a value of 0 (no sprouts) or 1 (successful sprouter), logistic regression was used to develop the statistical model (Wonnacott and Wonnacott 1979).

None of the other abiotic site factors (soils, oak site index), stand factors (brush cover, rock cover) or management factors (prescribed fire, grazing) were significant (equation 2; table 2). The negative sign on the coefficients for DBH, herbicides, crown cover percentage and slope percentage shows that these were negatively correlated with the probability of stump sprouting. Southerly slopes had a higher probability of sprouting than northerly slopes.

Height growth. With the data from the sample sites spanning a 10 -year period following harvest, it was possible to develop a model of 10-year sprout height growth. Since the functional form of sprout height growth was not known, the Box-Cox transformation $(\lambda)$ was utilized rather than imposing a linear or logarithmic form (Zarembka 1974).

The results of the analysis for blue oak sprout height growth are shown in equation 3. Other variables measured in the study, including site index, soil series, brush cover and prescribed fire were 
not significant. This can be transformed directly to the functional form shown in equations 4 and 5 to calculate predicted blue oak sprout height in feet (table 3).

Oak sprout height growth was quite vigorous in the sample areas, with the tallest sprout per clump averaging 8.2 feet, 9 years after harvest. The positive sign of the grazing coefficient indicates that the sprout height growth in grazed woodlands was higher than in ungrazed woodlands. The reason for the higher height growth on the grazed sites in this study area will need additional study to determine if seasonal grazing practices in the northern Sacramento Valley positively affect microsites to favor sprout growth, or if there is some other site factor correlated with grazing that was not included in this study.

Other studies have shown that voles can girdle blue oak seedlings and saplings (Tecklin et. al 2002; Tecklin and McCreary 1993). In both these studies, reducing ground vegetation via herbicides or grazing significantly limited vole damage to planted oaks. However, the long-term impacts of grazing may offset initial reductions in vole damage. A 19-year study of sprouting that compared grazed and ungrazed plots found significant increases in damage on grazed plots; cattle and deer apparently browsed sprouts so much that sprout survival, height and diameter were significantly lower (McCreary et. al 2008).

In the current study, the positive effects of grazing may be partially explained by reductions in initial vole damage, but it is still hard to reconcile these finding with those of McCreary et. al (2008). Additional research is needed to further clarify the relationship between grazing and sprout performance. The negative coefficient for overstory crown cover shows the competitive effect of overstory trees on understory sprout growth. Areas that received operational stump applications of herbicides had lower height growth than those where no herbicides were applied.

Crown growth. The same Box-Cox transformation process was used to develop a model of the crown area of the sprout cluster following harvest. Equation 6 shows the significant variables for the Box-Cox equation. Other variables measured in the study, including site index, soil series, brush cover and
EQUATIONS 3-7: Blue oak sprout height and crown growth

(3) Variables in sprout height analysis:

$$
\mathrm{HT}_{i}^{(\lambda)}=\mathrm{a}_{0}+\mathrm{a}_{1} \mathrm{AGE}^{(\lambda)}+\mathrm{a}_{2} \mathrm{HERB}^{(\lambda)}+\mathrm{a}_{3} \operatorname{GRAZE}^{(\lambda)}+\mathrm{a}_{4} \mathrm{CC}^{(\lambda)}+\mathrm{a}_{5} \operatorname{SPEC}^{(\lambda)}
$$

(4) Transformation to sprout height in feet:

$$
\begin{aligned}
& \frac{\mathrm{HT}^{(\lambda)}-1}{\lambda}=0.5958+0.3811 \frac{\mathrm{AGE}^{0.55}-1}{0.55}-0.4509 \frac{\mathrm{HERB}^{0.55}-1}{0.55}+0.3229 \frac{\mathrm{GRAZE}^{0.55}-1}{0.55}-0.9915 \frac{\mathrm{CC}^{0.55}-1}{0.55} \\
& \text { (5) } \quad \mathrm{HT}=\left(2.0657+0.3811 \mathrm{AGE}^{0.55}-0.4509 \mathrm{HERB}^{0.55}+0.3229 \mathrm{GRAZE}^{0.55}-0.995 \mathrm{CC}^{0.55}\right)^{(1 / 0.55)}
\end{aligned}
$$

(6) Variables in crown growth model:

$$
\operatorname{CROWN}_{i}^{(\lambda)}=a_{0}+a_{1} A_{G E}^{(\lambda)}+a_{2} \operatorname{HERB}^{(\lambda)}+a_{3} D B B H^{(\lambda)}+a_{4} \operatorname{GRAZE}^{(\lambda)}+a_{5} C^{(\lambda)}
$$

\begin{tabular}{|c|c|c|}
\hline Variable & Sprout height & Crown area \\
\hline & \multicolumn{2}{|c|}{ 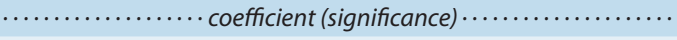 } \\
\hline Dependent variable & $\begin{array}{l}\mathrm{HT}=\text { total sprout height, } \\
\text { age } i\end{array}$ & $\begin{array}{c}\text { CROWN }=\text { total crown area in } \\
\text { square feet, age } i\end{array}$ \\
\hline$a_{0}=$ constant & $0.5958\left(^{* * *}\right)$ & $0.9947(* *)$ \\
\hline$\lambda=$ Box-Cox transformation coefficient & 0.55 & 0.37 \\
\hline AGE = age of sprouts in years since harvest & $0.3811\left(^{* * *}\right)$ & $0.7609\left(^{* * *}\right)$ \\
\hline $\begin{array}{l}\text { HERB }=\text { cut stump treated with herbicide } \\
(1=\text { yes, } 0=\text { no })\end{array}$ & $-0.4509\left(^{* *}\right)$ & $-0.5847\left(^{* * *}\right)$ \\
\hline $\begin{array}{l}\text { GRAZE }=\text { livestock grazing present } \\
(1=\text { grazed, } 0=\text { ungrazed })\end{array}$ & $0.3229\left({ }^{* * *}\right)$ & $0.5858(* *)$ \\
\hline $\begin{array}{l}\mathrm{CC}=\text { postharvest overstory crown cover } \\
\text { (expressed as decimal between } 0 \text { and } 1 \text { ) }\end{array}$ & $-0.9915\left(^{* *}\right)$ & $-3.1357(* * *)$ \\
\hline $\begin{array}{l}\mathrm{DBH}=\text { preharvest diameter at breast height } \\
\text { in inches }\end{array}$ & NA & $\left.0.07611^{* *}\right)$ \\
\hline $\mathrm{R}^{2}$ & $0.58(* * *)$ & $0.52(* * *)$ \\
\hline
\end{tabular}

(7) Transformation to crown growth in feet:

$$
\begin{gathered}
\mathrm{CROWN}=\left(3.6656+0.7609 \mathrm{AGE}^{(0.37)}-0.5847 \mathrm{HERB}^{(0.37)}+0.0761 \mathrm{DBH}^{(0.37)}+\right. \\
\left.0.5858 \operatorname{GRAZE}^{(0.37)}-3.1357 \mathrm{CC}^{(0.37)}\right)^{(1 / 0.37)}
\end{gathered}
$$

TABLE 3. Box-Cox regression of blue oak sprout height growth and crown area
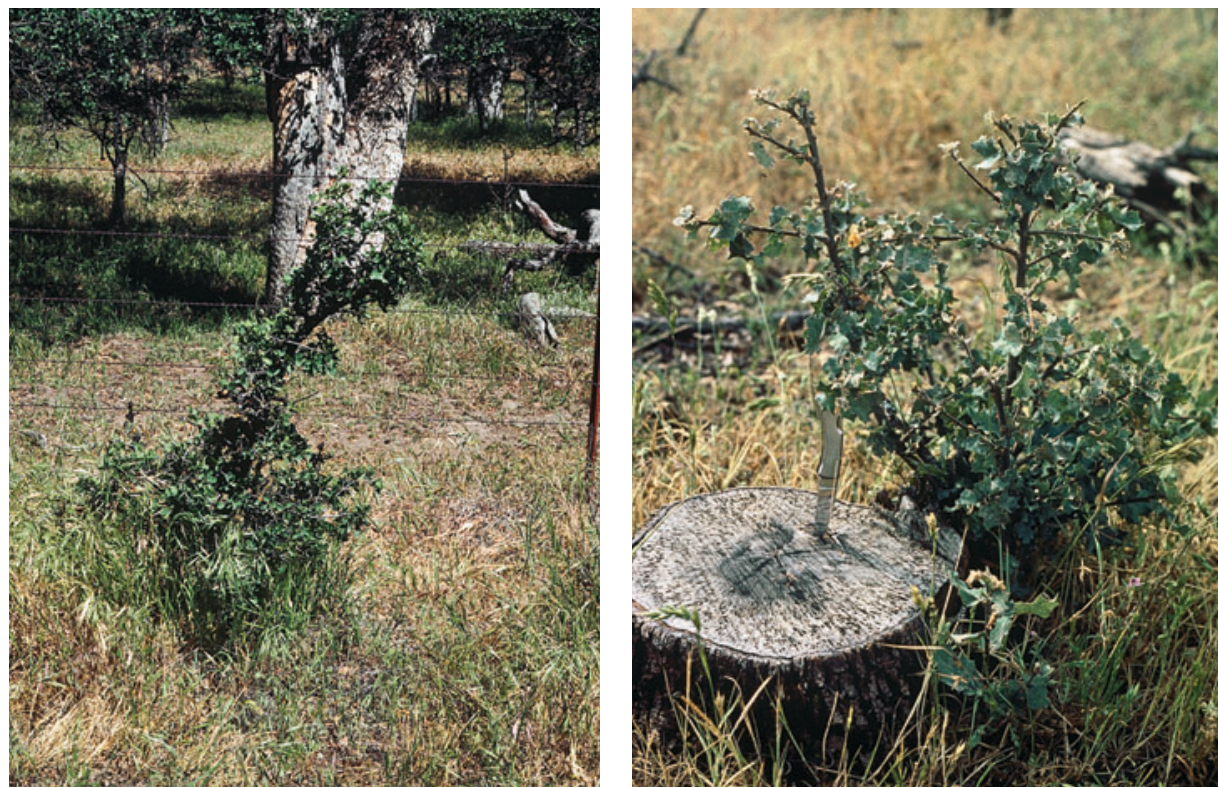

Statistical models were developed to predict the probability of resprouting under various conditions, including stump diameter, site slope and aspect, and herbicide treatments. 

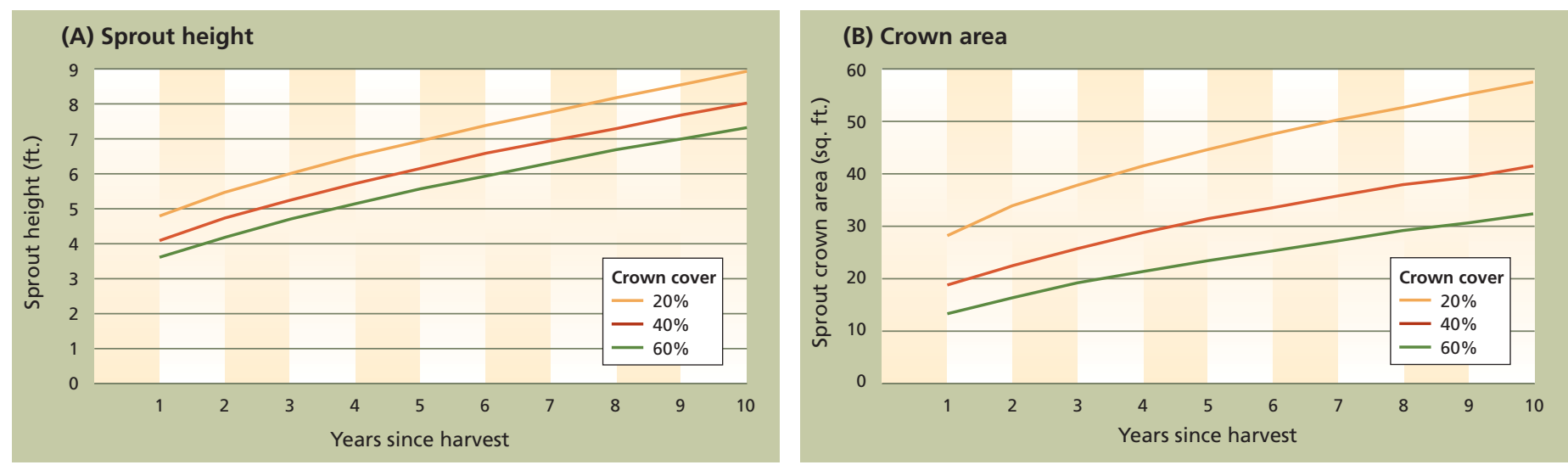

Fig. 2. Predicted blue oak (A) sprout height and (B) crown area in northern Sacramento Valley (10\% south slope, grazed, no herbicides) for $20 \%$, $40 \%$ and $60 \%$ crown cover (overstory canopy).

prescribed fire were not significant (table 3). Equation 7 uses the same transformation process as the sprout height model above, to provide a direct estimate of individual sprout cluster crown area in square feet.

The results for crown growth are similar to those for height, with positive effects from areas with grazing and tree size (represented by preharvest DBH), and negative effects from the operational

\section{In general, smaller trees have relatively good sprouting potential, while larger trees have poorer capacity for sprouting.}

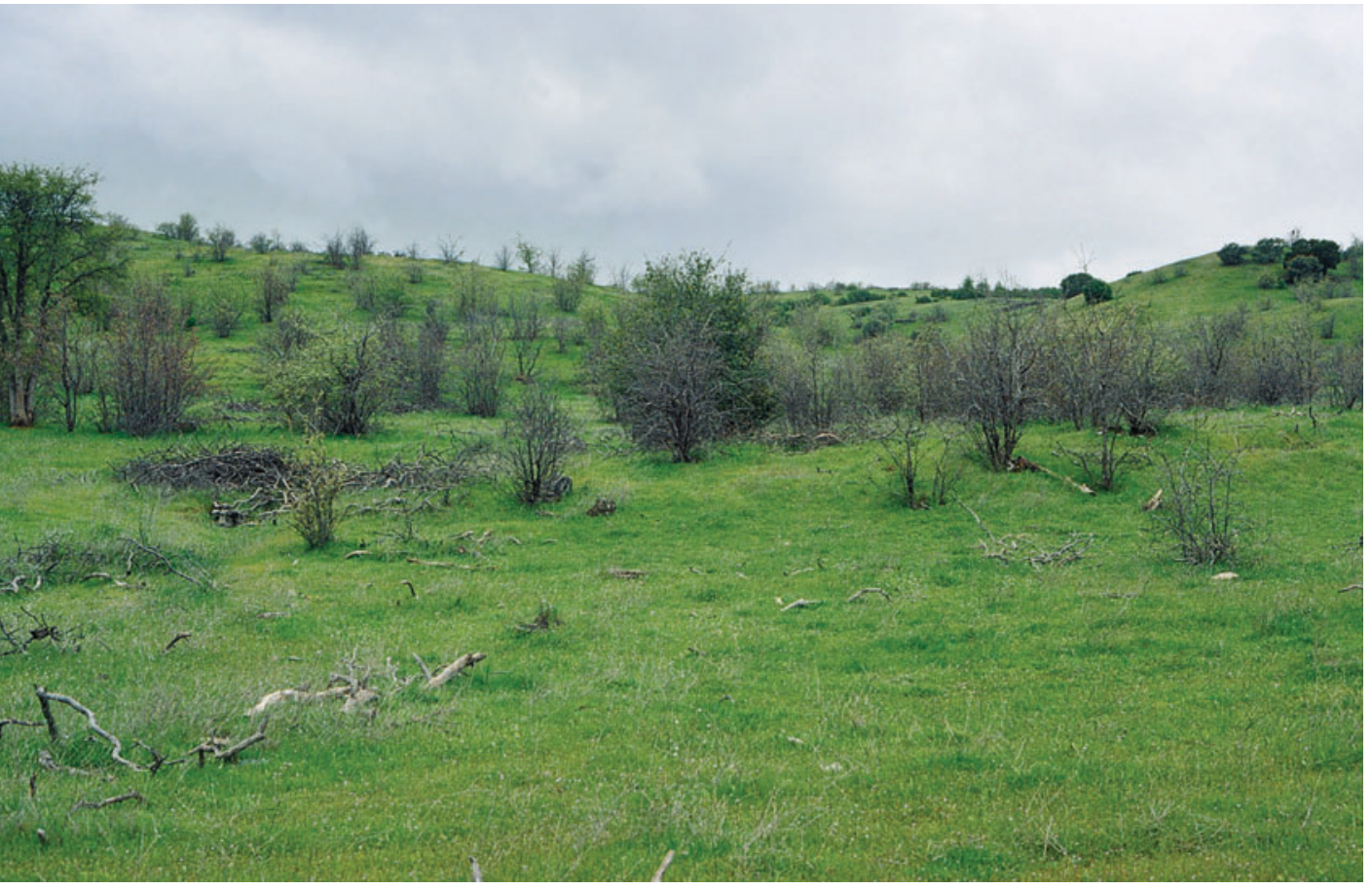

Managers will need to consider grazing seasons and intensity when developing plans that allow for adequate oak regeneration.

herbicide stump treatment and overstory canopy competition.

\section{Regenerating oak woodlands}

The models that we developed provide tools that can be used to evaluate the development of stand structure on hardwood rangeland following harvest, based on site and tree characteristics. The results can predict the probability of stump sprouting, as well as the height and crown development of sprouts following tree harvest, and can be used to assess the impact of oak harvest on forage production (Frost et al. 1997) and wildlife habitat (Garrison and Standiford 1997). The models can also be used in conjunction with overstory tree growth models (Standiford 1997) to provide whole-stand dynamics of managed hardwood rangelands.

Residual overstory canopy cover has a larger effect on crown area than height (fig. 2). Predicted sprout height is approximately $17 \%$ taller 10 years after harvest with an overstory of 20\% (8.9 feet) than of $60 \%$ (7.3 feet). Crown area after 10 years is more than $44 \%$ greater with an overstory of $20 \%$ (57.7 square feet per stump cluster) than of $60 \%$ (32.3 square feet per stump cluster).

\section{Predicting sprout development}

The relationships developed in this study can be used to predict sprout development for a blue oak thinning prescription (see sidebar, page 153). The sprouting probability, height growth and crown development assessed can help to provide an assessment of the adequacy of stump sprouting as an effective regeneration tool.

This study showed a lack of significance for the oak site index - a standard measure of forest productivity — based on a height-diameter relationship (Standiford and Howitt 1988). This was surprising and merits further study. To refine future work on the importance of site quality, it may be necessary to rely on a more detailed evaluation of the soil and rainfall characteristics of a site, or the construction of more typical height-age site index curves. 


\section{Predicting sprout development following thinning}

The results of this study can be used
to predict sprout development in a thinned blue oak stand. Our example stand is on a grazed property, where the objectives of thinning are to provide good forage for a cow-calf livestock enterprise, improve habitat for fee hunting, provide cash flow through the sale of firewood products and maintain long-term biodiversity (Standiford and Tietje 1990) (table 4). The harvest is designed to remove approximately $50 \%$ of all stems less than 12 inches diameter at breast height $(\mathrm{DBH}=4.5$ feet $)$ and to retain all trees 12 inches and larger. All cut stumps will be allowed to resprout. This example stand is on a south aspect with an average slope of $10 \%$

An average of approximately 135 stems per acre will be harvested, representing the removal of just over $40 \%$ of the basal area of the initial stand, reducing the crown cover from $45 \%$ to $26 \%$ (table 4 ). The harvest removes 417 cubic feet per acre, representing just under five cords per acre of firewood.

Equations developed in this study can be used to predict the probability of stump sprouting, sprout height growth and canopy development (table 5). Equation 2 is used to estimate the probability of stump sprouting for the different-size trees harvested (see page 150). The 2-inch trees harvested have a
$79.7 \%$ probability of sprouting, and the 10 -inch trees have a $69.8 \%$ probability. The average sprout height after 10 years for this grazed stand, with no herbicides applied, is calculated using equation 5 (see page 151) and is estimated to average 8.6 feet. The predicted crown development of the stump sprouts is calculated from equation 7 (see page 151) for the various tree sizes harvested. The total crown area of stump resprouts is just over 5,144 square feet per acre, representing $11.8 \%$ canopy cover.

These projections of stump sprouting and sprout development can be evaluated to determine if adequate regeneration is anticipated to meet the landowner's

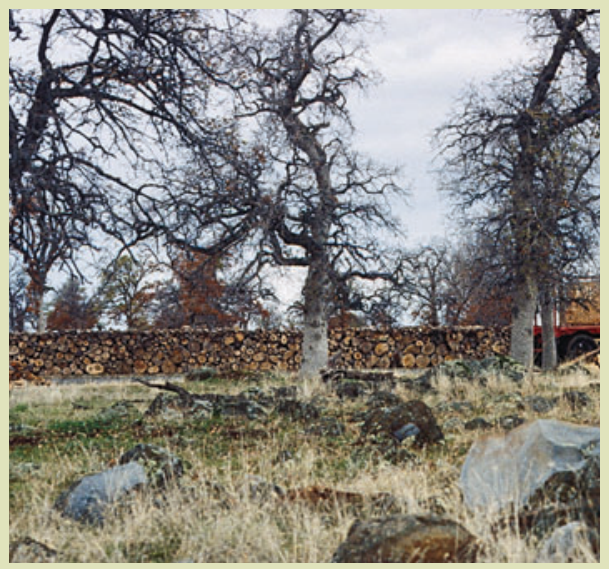

In Shasta County, harvested firewood is stacked in the study area.

objectives, or if the harvest prescription needs to be modified or additional tree planting needs to be considered.
TABLE 5. Sprout development for cut trees (grazed, no herbicide, $26 \%$ residual overstory cover, $10 \%$ south slope)

\begin{tabular}{lccccc}
\hline $\begin{array}{l}\text { DBH class, } \\
\text { inches* }\end{array}$ & Stumps & $\begin{array}{c}\text { Probability of } \\
\text { sproutingt }\end{array}$ & $\begin{array}{c}\text { Stumps with sprouts } \\
\text { number/acre }\end{array}$ & $\begin{array}{c}\text { Avg. crown area } \\
\text { per class }\end{array}$ & $\begin{array}{c}\text { Crown area in } \\
\text { class }\end{array}$ \\
\hline 2 & 4.44 & 0.799 & number/acre & $\ldots \ldots$. square feet/acre....... \\
4 & 28.89 & 0.776 & 22.43 & 49.25 & 174.90 \\
6 & 53.33 & 0.752 & 40.10 & 50.16 & $1,124.95$ \\
8 & 35.56 & 0.726 & 25.80 & 50.82 & $2,037.67$ \\
10 & 13.33 & 0.698 & 9.30 & 51.35 & $1,324.84$ \\
Total & 135.56 & & 101.18 & 51.81 & 481.98 \\
\hline
\end{tabular}

* Diameter at breast height ( 4.5 feet).

† From equation 2 ; average sprout height at 10 years $=8.6$ feet (from equation 5 ).

₹ From equation 7 .

$\S$ Sprout layer crown cover percentage at 10 years $=11.8 \%$

TABLE 4. Inventory data for blue oak thinning project in California's northern Sacramento Valley*

\begin{tabular}{|c|c|c|c|c|c|c|c|c|c|}
\hline \multirow{2}{*}{$\begin{array}{l}\text { DBH class, } \\
\text { inchest }\end{array}$} & \multicolumn{3}{|c|}{ Trees } & \multicolumn{3}{|c|}{ Basal area } & \multicolumn{3}{|c|}{ Volume } \\
\hline & Initial & Harvest & Residual & Initial & Harvest & Residual & Initial & Harvest & Residual \\
\hline & 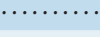 & umber/acr & $\ldots \ldots$ & ....... & lare feet/a & $\ldots \ldots$ & 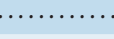 & bic feet/a & …... \\
\hline 2 & 6.67 & 4.44 & 2.22 & 0.27 & 0.16 & 0.11 & 1.32 & 0.76 & 0.56 \\
\hline 4 & 57.78 & 28.89 & 28.89 & 6.23 & 3.06 & 3.17 & 47.35 & 23.25 & 24.09 \\
\hline 6 & 104.44 & 53.33 & 51.11 & 20.51 & 10.49 & 10.02 & 223.52 & 111.65 & 111.87 \\
\hline 8 & 71.11 & 35.56 & 35.56 & 24.36 & 12.31 & 12.05 & 330.61 & 168.45 & 162.16 \\
\hline 10 & 26.67 & 13.33 & 13.33 & 14.06 & 12.18 & 1.89 & 221.27 & 112.90 & 108.37 \\
\hline 12 & 8.89 & 0.00 & 8.89 & 7.00 & 0.00 & 7.00 & 120.17 & 0.00 & 120.17 \\
\hline 14 & 2.22 & 0.00 & 2.22 & 2.11 & 0.00 & 2.11 & 43.72 & 0.00 & 43.72 \\
\hline 16 & 0.00 & 0.00 & 0.00 & 0.00 & 0.00 & 0.00 & 0.00 & 0.00 & 0.00 \\
\hline 18 & 2.22 & 0.00 & 2.22 & 4.38 & 0.00 & 4.38 & 110.27 & 0.00 & 110.27 \\
\hline 20 & 2.22 & 0.00 & 2.22 & 4.95 & 0.00 & 4.95 & 147.66 & 0.00 & 147.66 \\
\hline 22 & 0.00 & 0.00 & 0.00 & 0.00 & 0.00 & 0.00 & 0.00 & 0.00 & 0.00 \\
\hline 24 & 2.22 & 0.00 & 2.22 & 6.58 & 0.00 & 6.58 & 153.87 & 0.00 & 153.87 \\
\hline Totals & 284.44 & 135.56 & 148.89 & 90.44 & 38.20 & 52.24 & 1,399.77 & 417.02 & 982.75 \\
\hline
\end{tabular}

* Crown cover: initial $=45 \%$; harvest $=19 \%$; residual $=26 \%$.

† Diameter at breast height (4.5 feet). 
continued from page 152

Our sample size of interior live oak was insufficient in the study area to make conclusive statements about its sprouting performance. This will require future studies focused directly on interior live oak. Furthermore, this work was only able to evaluate the presence or absence of grazing as a management strategy. As mentioned, McCreary et al. (2008) showed that herbivory of unprotected blue oak sprouts from both livestock and wildlife had a major effect on sprout survival and growth when compared to ungrazed controls. The positive effect of the grazing coefficient in this study contrasts with McCreary et al.'s (2008) statewide, controlled experiment. Further refinement of the grazing strategy, in terms of season and intensity of use, is necessary to determine an appropriate grazing prescription that provides for adequate stand regeneration.

In general, smaller trees (less than 12 inches $\mathrm{DBH}$ ) have relatively good sprouting potential, while larger trees have poorer capacity for sprouting. Since sprouting vigor decreases for larger tree sizes, the retention of larger trees (over 12 inches $\mathrm{DBH}$ ) for habitat value (mast production/acorns used as a wildlife food source, cavity sites, snag and woody debris recruitment) is appropriate. Where large trees are removed, it may be necessary to plant oak seedlings to ensure the replacement of harvested trees.

\section{R.B. Standiford is Cooperative Extension Forest} Management Specialist, UC Berkeley; D. McCreary is Cooperative Extension Natural Resource Specialist Emeritus, UC Berkeley; S. Barry is Livestock and Natural Resource Advisor, UC Cooperative Extension (UCCE) Santa Clara County; and L. Forero is Livestock Advisor, UCCE Shasta and Trinity counties.

We thank the ranching families of Shasta and Tehama counties who allowed this study to take place on their lands. We also thank the California Department of Forestry and Fire Protection for funding. We appreciate the tremendous support of the late Ron Knight, Livestock Advisor Emeritus in Tehama County, who helped to contact cooperators and assisted with field data collection.

\section{References}

Allen BH, Holzman BA, Evett RR. 1991. A classification system for California's hardwood rangelands. Hilgardia 59(2):1-45.

Bartolome JW. 1987. California annual grassland and oak savannah. Rangeland 9(3):122-5.

Bolsinger CL. 1988. The Hardwoods of California's Timberlands, Woodlands, and Savannas. USDA Forest Service Pac NW Res Sta Res Bull PNW-RB-148. 49 p.

Clark FB, Liming FG. 1953. Sprouting of blackjack oak in the Missouri Ozarks. USDA Forest Service Central States Forest Exp Sta Tech Paper No 137. Central States Forest Experiment Station. Columbus, OH. 18 p.

Clawson WJ, McDougald NK, Duncan DA. 1982. Guidelines for Residue Management on Annual Range. UC DANR Leaflet No 21327. 3 p.

Dey DC, Jensen RC, Wallendorf MJ. 2008. Single-tree harvesting reduces survival and growth of oak stump sprouts in the Missouri Ozark highlands. In: Proc 16th Central Hardwood Forest Conf, April 8-9, 2008, West Lafayette, IN. USDA Forest Service Gen Tech Rep NRS-P-24. p 26-37.

Frost WE, Bartolome JW, Connor JM. 1997. Understorycanopy relationships in oak woodlands and savannas. In: Proc Symp Oak Woodlands: Ecology, Management, and Urban Interface Issues, March 19-22, 1996, San Luis Obispo, CA. USDA Forest Service Gen Tech Rep PSWGTR-160. p 183-90.

Garrison B. 1996. Vertebrate wildlife species and habitat associations. In: Standiford RB, Tinnin P (eds.). Guidelines for Managing California's Hardwood Rangelands. UC DANR Leaflet No 3368.

Garrison B, Standiford RB. 1997. A post-hoc assessment of the impacts to wildlife from woodcutting in blue oak woodlands in the northern Sacramento Valley. In: Proc Symp Oak Woodlands: Ecology, Management, and Urban Interface Issues, March 19-22, 1996, San Luis Obispo, CA USDA Forest Res Paper PSW-GTR-160. p 411-22.

Geisinger DR, Waldrop TA, Haymond JL, Van Lear DH. 1989. Sprout growth following winter and spring felling with and without summer broadcast burning. In: Waldrop TA (ed.). Proc Pine-hardwood Mixtures: Symp Management and Ecology of the Type; April 18-19: Atlanta, GA. Gen Tech Rep SE-58. USDA Forest Service, Southeastern Forest Experiment Station. Asheville, SC. p 91-5. Huntsinger L, Buttoloph L, Hopkinson P. 1997. Ownership and management changes on California hardwood rangelands: 1985 to 1992. J Range Manage 50(4):423-30. Jepson WL. 1910. The Silva of California. Memoirs of the University of California. Vol 2. Berkeley, CA: Univ Pr. 480 p.
Johnson PS. 1975. Growth and structural development of red oak sprout clumps. Forest Sci 21(4):413-8.

Johnson PS. 1977. Predicting Oak Stump Sprouting and Sprout Development in the Missouri Ozarks. Res Paper NC-149. North Central Forest Experiment Station, USDA Forest Service. St. Paul, MN. 11 p.

Johnson PS. 1979. Shoot elongation of black oak and white oak sprouts. Can J Forest Res 9:489-94.

Leiberg JB. 1902. Forest Conditions in the Northern Sierra Nevada, California. US Geological Survey Professional Paper 8. Washington, DC. 194 p.

Liming FG, Johnston JP. 1943. Reproduction in oakhickory forest stands of the Missouri Ozarks. J Forestry 42(3):175-80.

Lockhart BR, Chambers JL. 2007. Cherrybark oak stump sprout survival and development five years following plantation thinning in the lower Mississippi alluvial valley, USA. New Forest 33:183-92.

Longhurst WM. 1956. Stump sprouting of oaks in response to seasonal cutting. J Range Manage 9(4):194-6. McClaren MP, Bartolome JW. 1989. Fire-related recruitment in stagnant Quercus douglasii populations. Can J Forest Res 19:580-5.

McCreary DD, Tietje WD, Frost WE. 2008. Stump sprouting of blue oaks 19 years after harvest. In: Proc Sixth Symp on Oak Woodlands: Today's Challenges, Tomorrow's Opportunities. USDA Forest Service Gen Tech Rep PSWGTR-217. p 333-41.

Mensing SA. 1992. The impact of European settlement on blue oak (Quercus douglasii) regeneration and recruitment in the Tehachapi Mountains, California. Madroño 39(1):36-46

Pavlik B, Muick P, Johnson S, Popper M.1991. Oaks of California. Los Olivos, CA: Cachuma Pr. 184 p.

Pillsbury NH, Kirkley ML.1987. Equations for Total, Wood, and Saw-log Volume for Thirteen California Hardwoods. Res Note PNW-414. Pacific Northwest Forest and Range Experiment Station, USDA Forest Service. Portland, OR. $52 \mathrm{p}$

Plumb TR, Gomez AP. 1983. Five Southern California Oaks: Identification and Postfire Management. Gen Tech Rep PSW-71. Pacific Southwest Forest and Range Experiment Station, USDA Forest Service. Berkeley, CA. 56 p.

Rogers DJ, Rogers PH. 1959. Sprouting Capacity of Oak Stumps in Southern Wisconsin. Univ Wisc Forest Res Notes. 3 p.

Roth ER, Hepting GH. 1943. Origin and development of oak stump sprouts as affecting their likelihood to decay. J Forestry 41:27-36.
Standiford RB. 1997. Growth of blue oak on California's hardwood rangelands. In: Proc Symp Oak Woodlands: Ecology, Management, and Urban Interface Issues, March 19-22, 1996, San Luis Obispo, CA. USDA Forest Res Paper PSW-GTR-160. p 169-76.

Standiford RB. 2001. California's oak woodlands. In: McShea WJ, Healy WM (eds.). Oak Forest Ecosystems: Ecology and Management for Wildlife. Baltimore, MD: Johns Hop kins Univ Pr. p 280-303.

Standiford RB, Howitt RE. 1988. Oak stand growth on California's hardwood rangelands. Cal Ag 42(4):23-4.

Standiford RB, Howitt RE. 1993. Multiple use management of California's hardwood rangelands. J Range Manage 46:176-81

Standiford RB, McCreary D, Gaertner S, Forero L. 1996. Impact of firewood harvesting on hardwood rangelands varies with region. Cal $\mathrm{Ag} \mathrm{50(2):7-12.}$

Standiford RB, McDougald N, Frost W, Phillips R. 1997. Factors influencing the probability of oak regeneration on southern Sierra Nevada woodlands in California. Madroño 44(2):170-83.

Standiford RB, Tietje W. 1990. Harvesting Firewood for Sustained Yield on Oak Rangelands. UC DANR Pub No 21487. 30 p.

Tecklin J, Conner JM, McCreary DD. 2002. Rehabilitation of an oak planting project on cleared rangeland using treeshelters and grazing. In: Proc Fifth Symp Oak Woodlands: Oaks in California's Changing Landscape, Oct. 22-25, 2001, San Diego, CA. USDA Forest Service Gen Tech Rep PSW-GTR-184. p 839.

Tecklin J, McCreary DD. 1993. Dense vegetation may encourage vole damage in young oak plantings. Restorat Manage Notes 11(2):153.

Weigel DP, Dey DC, Peng CJ. 2006. Stump sprout dominance probabilities of five oak species in Southern Indiana 15 years after clearcut harvesting. In: Proc 13th Biennial Southern Silviculture Research Conference. USDA Forest Service Gen Tech Rep SRS-92. p 551-8. Weigel DP, Peng CJ. 2002. Predicting stump sprouting and competitive success of five oak species in southern Indiana. Can J Forest Res 32:703-12.

Wonnacott RJ, Wonnacott TH. 1979. Econometrics. New York, NY: J Wiley. 580 p.

Zarembka P. 1974. Frontiers of Econometrics. New York, NY: Acad Pr. 252 p. 